\title{
Evaluation Program for Special Class of Sport in Senior High School Level
}

\author{
Ridho Gata Wijaya \\ Faculty of Sports Science \\ Universitas Negeri Surabaya \\ Surabaya, Indonesia \\ ridhogata42@gmail.com
}

\author{
Nurhasan \\ Faculty of Sports Science \\ Universitas Negeri Surabaya \\ Surabaya, Indonesia \\ Nurhasan_007@yahoo.com
}

\author{
Edy Mintarto \\ Faculty of Sports Science \\ Universitas Negeri Surabaya \\ Surabaya, Indonesia \\ edytrack@unesa.ac.id
}

\begin{abstract}
The aim of this paper is to make a proper analysis on the evaluation of the special class sports program at the Yogyakarta senior high school level. The objective of this study consisted of 5 schools in four different districts. The data collection was done using a mixed method that included 149 respondents and that was made up of 13 teachers, 28 coaches, and 108 students. This research is qualitative and descriptive with a CIPP approach that aims to evaluate and compile the program of the special class sports program in Yogyakarta. The result of this study can be concluded that the management of the special class of the sports program is in a quite good category (the average score is 3.18 in the scale 1 to 4). Out of 149 respondents; $41.6 \%$ was declared good; $\mathbf{5 7 . 0 \%}$ is good enough; and $\mathbf{1 . 3 \%}$ are not good. In addition, the results also indicate that students, teachers, and coaches consider that special sports classes are in a good category.
\end{abstract}

\section{Keywords - evaluation program, special sport class}

\section{INTRODUCTION}

The existence of a demographic bonus in 2020-2030 estimates that Indonesia will have a large population. The impact of this context is the increase in educational needs. The improvement of the quality of education is regulated in UU no. 20 of 2003. As a formal educational institution responsible for the implementation of national educational objectives, the educational unit must organize an educational process aimed at improving the quality of its productivity. One of them is the development of sports education in Indonesia, regulated by the SKN (National Sports System). To develop sports activities in all areas of education, establishment of sports activities units, sports classes, training and coaching centers, sports and sports schools and sustainable sports has to be put in place.

Sports schools are organized as extracurricular activities outside of school hours [1]. This sports program aims to increase the sports participation of young people through the School Sports Partnership Program (SSPP). The three characteristics of high-quality sports schools include: 1) the participation of young people, regardless of their situation or skills, to participate and practice sports; 2) promote the health, safety, and well-being of young people; and 3) it allows all young people to improve and be successful according to their age and potential.

A large number of potential athletes and sports policies is a good step which serves as a basic asset to open a special path that can be considered a subsystem of the national sport. Therefore, its event must be planned strategically through appropriate evaluation efforts. In a training program called the School Sports Program Coordinator who aims to develop and provide opportunities for young athletes in schools, both inside and outside the normal curriculum.

In a particular type of sports program, schools with communities should actively participate in developing partnerships in training centers to improve athletic abilities in improving popular sports. This is consistent with the goal of forming a special type of sport as a means of selecting high-level performing students and training students to become successful athletes. The development of a sports class must adopt a program developed by a sports federation selected to divide athletes into age groups or skill groups. This goes to the position that the students can be clearly mapped, whether beginner, advanced or skillful. The curriculum becomes a problem in the implementation of the KKO program where schools do not have a clear basis for the program to use as a guide for the development of athletes [2].

As a result, schools should be able to develop policies that make the program effective and sustainable. To determine the appropriate program policies, several standards must be taken into account in the implementation of the strategic plan, which includes: (1) Standard of infrastructure and facilities; (2) system of recruiting potential students. In addition to the physical, mental, emotional and moral potential, athletes must complete a series of physical and motor fitness tests. (3) minimum service standard and training process; (4) sports class implementation model; 5) recruitment of personnel; (6) life center skills. In this case, the students of the sports class are required to acquire the necessary skills to be successful in the future.

The CIPP evaluation method is an appropriate evaluation model for problem mapping. The overuse of this model is found in the four components that relate to context, inputs, processes, and products to offer advice and contributions related to the condition of a special class sports program.

\section{SPECIAL SPORTS ClaSs}

Sport can be identified as "inner horizon" characteristic that is essentially shaped by plays and games. Therefore, true action in sport is not an unpleasant one, but it is also the source of joy and happiness [3]. So that the balance of physical and psychological conditions can be achieved by 
human efforts through sports and recreational activities aimed at reducing the feeling of tension, refreshing and relaxing. The implementation of sports programs by sports administrators is one of the crucial parts to achieving success [4]. Programming is the process of developing a sports plan, while implantation is the fulfillment of a planned sports program involving human and material resources.

\section{A. Special Sports Class}

The establishment of a special class of sport is a model of school training that involves a group of students identified as "talented" athletes within the reach of the school [2]. It is also a meeting point for athletes who are still sitting in school to receive continuous training related to sports talent. A special sports classes program is established to: a) serve as a training center for potential student-athletes to achieve national and international achievements; (b) encourage the sportsman to have a great spirit to boost the nation and the state; c) promote the academic performance of the student-athlete to support future guarantees (Kep Dirnjen Diknaspora Depdikbud). The implementation of a policy on the application of a particular type of sport is in accordance with paragraph 6 of article 25 of the SKN Law: to develop sports achievements in the educational institution, in every educational path can be established sports activities units, sports classes, training and coaching centers, sports schools, tiered and sustainable sports competition".

In most developed countries, children spend more time in school. Encourages schools to provide physical facilities to support their embodied activities by purchasing sports specialties at the senior secondary school level [5]. This research focuses on the development of sports school policy based on the physical environment of the school. Koplan et al., In 2005, the Institute of Medicine recommended that intramural/indoor sports introduce more widely in schools to meet the needs of students with different abilities. Includes students who do not have the time, skills or confidence to participate in sports at school. In some schools, sports classes led to the practice of specialization in certain sports sectors.

Based on the research carried out by Andrei and Peter $(2,017)$, special programs of sports classes have an added value for students, including:

a. Students gain a better understanding of the contribution of Sports Education units through the learning and experience process.

b. Giving a more serious learning to students.

c. Students can learn by watching classmates during the game or when they are not in the game.

d. Students can learn by watching other friends during the game or not in the game. e. Having a well-informed or knowledgeable instructor.

\section{B. The Aims of Special Class of Sport}

The success of the implementation depends on the proper programming of the target. In the management guide published by the Directorate General of Elementary and Secondary Education in 2010, the objective of the sports classes are:

a. Optimizing students' talents and interests in sports.

b. Optimizing the quality of academic services and achievements in sports.

c. Optimizing an athlete's ability to compete by instilling sportsmanship value.

d. Optimize the program in schools maximally in the development and coaching of sports activities.

e. Optimizing the physical and spiritual health of learners.

f. Optimizing school quality to be a place in character building for learners.

\section{Coaching Program of Special Class of Sport}

Successful coaching can be done by studying the worldclass experience of the coach so that it can be used by other trainers [6]. In his research he employed the use of crosssectional analysis of three Australian sports teams, concluding that effective coaching includes the use of good social skills, personal characteristics and organizational skills. Coaching coaches should focus on the mental needs of the athletes [7]. It can be more effective and help encourage athletes through proper intervention media. Therefore, athletic athletes can use the coaching style used while playing for better performance. Everyone, therefore, needs a special leadership style used by athletes to maintain a level of mental health and satisfaction, during or after the training program. The implication of a study of athletes or players involved in a team is that athletes should be trained in appropriate coaching methods and strategies to improve mental fitness as they continue playing. The influence of the study on coaching needs to be considered in order to ensure that information techniques and training styles provided to athletes are effective.

\section{METHODS}

This research is used in conjunction with the CIPP approach, which is a research method combining two methods, qualitative data as primary data and secondary or quantitative data. A combination of qualitative and quantitative research is a combination of research methods that aim to achieve a more complete, valid, reliable and objective data analysis [8]. 
TABLE I.

SOURCES OF RESEARCH DATA

\begin{tabular}{|c|c|c|c|c|c|}
\hline \multirow[b]{2}{*}{ School } & \multicolumn{5}{|c|}{ Primary Data } \\
\hline & $\begin{array}{l}\text { Head- } \\
\text { master }\end{array}$ & $\begin{array}{c}\text { Director of } \\
\text { the } \\
\text { program }\end{array}$ & $\begin{array}{c}\text { Physical } \\
\text { Education } \\
\text { teacher } \\
\end{array}$ & Coach & $\begin{array}{c}\text { Student/ athlete in } \\
\text { XI class }\end{array}$ \\
\hline $\begin{array}{l}4 \text { Yogyakarta Senior } \\
\text { High School }\end{array}$ & 1 & 1 & 2 & 5 & $( \pm) 32$ \\
\hline $\begin{array}{l}1 \text { Sewon Senior High } \\
\text { School }\end{array}$ & 1 & 1 & 2 & 5 & $( \pm) 32$ \\
\hline $\begin{array}{l}1 \text { Pengasih Senior High } \\
\text { School }\end{array}$ & 1 & 1 & 2 & 5 & ( \pm ) 32 \\
\hline $\begin{array}{l}1 \text { Playen Senior High } \\
\text { School }\end{array}$ & 1 & 1 & 2 & 5 & ( \pm ) 32 \\
\hline $\begin{array}{l}1 \text { Seyegan Senior High } \\
\text { School }\end{array}$ & 1 & 1 & 2 & 5 & ( \pm ) 32 \\
\hline Total & 5 & 5 & 10 & 25 & 160 \\
\hline
\end{tabular}

To determine the number of students / athletes to be sampled can be done using a normally distributed population.

$$
n=\frac{N}{1+N e^{2}} \quad \begin{aligned}
& \mathrm{n}=\text { sample size } \\
& \mathrm{N}=\text { amount of population }
\end{aligned}
$$

\section{A. Technique of Data Analysis}

The analysis of the data obtained through questionnaires includes: 1); scoring of respondents' answers (director of the program/teacher, trainer, athlete/student); 2); summing the total score of each component 3) Ratings of the respondents according to the trend level. The score used for the study depends on the data collected and the respondents. For program managers, trainers and athletes who use scale 1 through $4(4,3,2$ and 1$)$.

TABLE II. SCORES TABLE

\begin{tabular}{lll}
\hline Response Options & Score $(+)$ & Score ( - ) \\
\hline SA (Strongly Agree) & 4 & 1 \\
A (Agree) & 3 & 2 \\
D (Disagree) & 2 & 3 \\
SD ( Strongly Disagree) & 1 & 4 \\
\hline
\end{tabular}

The data collected is included in the categorization of information units according to the principle that information can be interpreted without any added value. For similar information, data can be incorporated into a single category, so it is possible to display new categories of information already available. How to convert raw scores into percentage form using the formula: $\sum$ raw score $/ \sum$ maximum score $\mathrm{x} 100 \%$ = Percentage value

The analysis used in this research is descriptive qualitative. The quantitative descriptive analysis of this study uses categorization based on a normal distribution model (Syaifuddin Azwar, 2008: 106). Since the choice (answer option) of the study instrument consists of 4 options, then for the consistent description of the search results, four categories are also used:

$\left(\mathrm{M}_{\mathrm{i}}+1 \mathrm{SD}_{\mathrm{i}}\right)$ up to $\left(\mathrm{M}_{\mathrm{i}}+3 \mathrm{SD}_{\mathrm{i}}\right)=$ Very good/ Good category $\left(\mathrm{M}_{\mathrm{i}}\right)$ up to $\left(\mathrm{M}_{\mathrm{i}}+1 \mathrm{SD}_{\mathrm{i}}\right)=$ Enough/ Good Enough category

$\left(\mathrm{M}_{\mathrm{i}}-1 \mathrm{SD}_{\mathrm{i}}\right)$ up to $\left(\mathrm{M}_{\mathrm{i}}\right)=$ Deficient/ Not Good category

$\left(\mathrm{M}_{\mathrm{i}}-3 \mathrm{SD}_{\mathrm{i}}\right)$ up to $\left(\mathrm{M}_{\mathrm{i}}-1 \mathrm{SD}_{\mathrm{i}}\right)=$ Poor/ Very Poor category

Notes:

$\mathrm{Mi}=$ Ideal Mean = 1/2 $($ Maximum Score + Minimum Score $)$
$\mathrm{CDi}=$ Ideal Deviation Standard $=1 / 6$ (Maximum Score Minimum Score)

\section{B. Qualitative Data Analysis Technique}

The three main stages of qualitative data analysis techniques include: 1) Data reduction, data obtained from the program director, coach and sports class athlete report; 2) Data presentation (Display data) is a collection of information compiled from the results of data reduction; 3) The Taking conclusion (verification) of the data collected are incorporated into units of information to form categories with the principle that the data can be interpreted without any addition.

\section{RESULTS AND DISCUSSION}

This journal is a research on mixing methods that involve quantitative and qualitative research with the CIPP approach to evaluate the management of the special class of sport in high school. The data of this study were taken with observation, interview and dissemination of the instrument in the form of a questionnaire and the scores were carried out so that the data obtained are quantitative data, as well as the analysis of descriptive quantitative data with the percentage. 
The Likert scale is the scale of measurement used in this study, it consists of a range of scores between 1 to 4; so that obtained the ideal mean $=2.5$ and ideal $\mathrm{SD}=0.5$. The criteria assessment can be obtained from the mean and ideal SD on this evaluation study and presented in the following table.

\begin{tabular}{llll} 
TABLE III. & TABLE OF INTERPRETATION CRITERIA FOR EVALUATION STUDY RESUlTS IN THE SPECIAL CLASS OF SPORT \\
\hline No. & Assessment Norms & Score Range & Interpretation \\
\hline 1. & M+1,5SD up to M+3SD & $3,26-4,00$ & Good \\
2. & M up to M+1,5SD & $2,51-3,25$ & Good Enough \\
3. & Mi-1,5SDi up to Mi & $1,76-2,50$ & Not Good \\
4. & Mi-3SD up to Mi-1,5SDi & $1,00-1,75$ & Poor \\
\hline
\end{tabular}

The evaluation data on the special class of sports program are taken from the observation, the interview, and the questionnaire. Questionnaires are distributed to students, program directors and coaches; with a sample of 108 students; 13 teachers; and 28 coaches. In general, the results of the evaluation of special sports management obtained an average of 3.18 ; median $3.15 ; 3.08$ mode and standard deviation at 0.30 . The average score is in the range of 2.51 to 3.25 because the category is good. In this way, it is concluded that the management of a type of special class is in a quite good category.
Frequency distribution in the special sports class of management, as shown in the graph chart and histogram below:

TABlE IV. The Distribution Table of EValuation in Management SPecial Class of SPORT

\begin{tabular}{lllcc}
\hline \multirow{2}{*}{ No. } & Score category & Norms & \multicolumn{2}{c}{ Frequency } \\
\cline { 3 - 4 } & & $3,26-4,00$ & 62 & F \\
\hline 1. & Good & $2,51-3,25$ & 85 & 41,6 \\
2. & Good Enough & $1,76-2,50$ & 2 & 57,0 \\
3. & Not Good & $1,00-1,75$ & 0 & 1,3 \\
4. & Enough & & 149 & 0,0 \\
Total & & & & 100,0 \\
\hline
\end{tabular}

From the table above, the distribution of management special classes of sports programs can be presented in the form of a histogram as shown below:

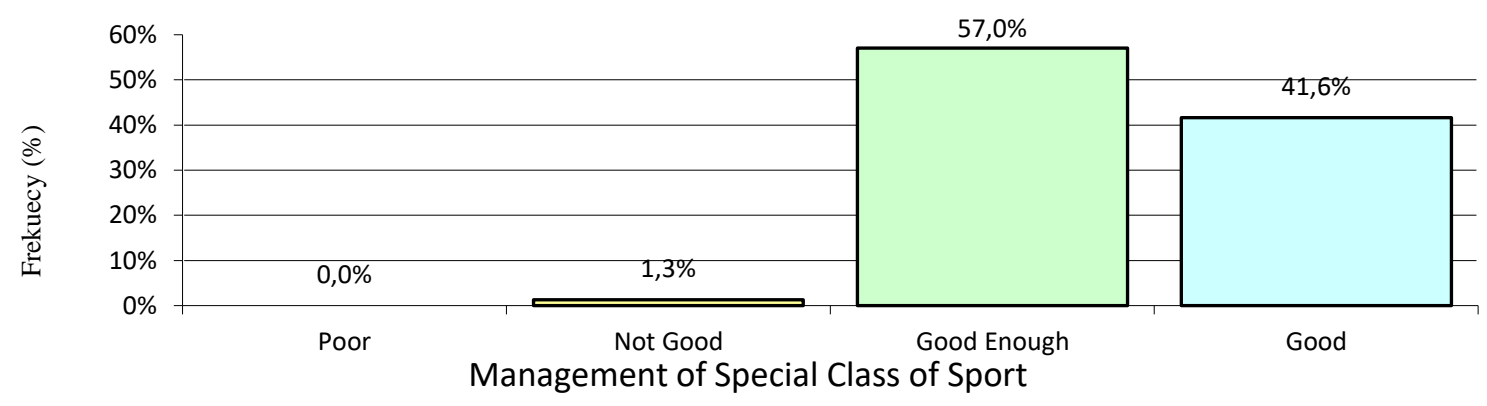

According to the frequency distribution mentioned, it appears that 149 respondents are research samples (students, teachers'/program directors and trainers); $41.6 \%$ stated good; $57.0 \%$ good enough, and $1.3 \%$ not good. The management of the special class of sport based on the average of each data source is shown in the following table. 


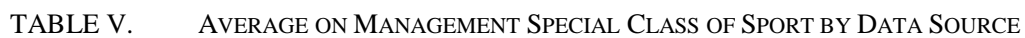

\begin{tabular}{llccl}
\hline No. Data Source & $\mathbf{N}$ & $\begin{array}{c}\text { Average } \\
\text { Score }\end{array}$ & Score Category \\
\hline $1 . \quad$ Student & 108 & 3,20 & Good enough \\
2. & $\begin{array}{l}\text { Teacher/Director of } \\
\text { Program }\end{array}$ & 13 & 3,25 & Good enough \\
3. $\quad$ Coach & 28 & 3,10 & Good enough \\
Avarage & $\mathbf{1 4 9}$ & $\mathbf{3 , 1 8}$ & Good enough \\
\hline
\end{tabular}

The table above shows that the management of the special class of sports according to students, teacher/head of the program, and the trainer is in good enough category.
The following is the result of the analysis of the sportsspecific class based on the average in each schools

TABle VI. Average Special Class of Sport Management Based on School

\begin{tabular}{llccl}
\hline No. & Data Source & N & Average Score & Score Category \\
\hline 1. & Lendah Senior High School & 32 & 3,16 & Good enough \\
2. & Ngaglik Senior High School & 28 & 3,08 & Good enough \\
3. & Tanjungsari Senior High School & 31 & 3,26 & Good enough \\
4. & Sewon Senior High School & 38 & 3,33 & Good enough \\
5. & 4 Yogyakarta Senior High School & 20 & 2,99 & Good enough \\
Average & $\mathbf{1 4 9}$ & $\mathbf{3 , 1 8}$ & Good enough \\
\hline
\end{tabular}

The table above shows that management of the special class of sport is based on student ratings, teacher/director of program and trainer at each school; in Tanjung sari and Sewon Senior High School are in good category; while at Lendah, Ngaglik, and 4 Yogyakarta Senior High School are in good enough category.

\section{CONCLUSION}

Based on the results of the study and the discussion, it can be observed that the management of a special class of sports programs is in the category of good enough (average score of 3.18 in a scale of 1 to 4). Of 149 respondents; $41.6 \%$ stated good; $57.0 \%$ stated good enough; and $1.3 \%$ stated not good; and nobody said poor. Based on the students' assessment, the teacher/director of the program and the trainer also show that the management of the special class of sport is in a sufficiently or rather good enough category.

The general context of the management of the sports class is in good condition. The input on the management of a special class of sports programs is in good enough category, and the product on management in the special class of sports program is also in good enough category.

\section{REFERENCES}

[1] A. Flintoff, The school sport co-ordinator programme: changing the role of the physical education teacher?. Sport, Education and Society. Vol. 8, Issue 2, 231-250. 2003.
[2] A. Mahendra, Artikel pokok-pokok pikiran manajemen kelas olahraga. Asdep Penerapan Iptek Keolahragaan Deputi Bidang Peningkatan Prestasi Olahraga Kementerian Pemuda Dan Olahraga Republik Indonesia. 2010.

[3] Sumaryanto. Aksiologi olahraga, dalam perspektif pengembangan karakter bangsa. Yogyakarta: UNY Press. 2016.

[4] T. Orunaboka, \& C. B. Ogulu, The impact of administration and sports programme implementation on the achievement of sports council at the 17th national sports Festival competition: a case study of rivers state sports council. 2015. Vol. 6 Issue 5, 32-37. DOI: 10.5897/JPESM2013.0176.

[5] J. N. Bocarro, M. A. Kanters, E. Cerin, M. F. Floyd, J. M. Casper, L. Suau, \& T. L. McKenzie, "School sport policy and school-based physical activity environments and their association with observed physical activity in middle school children," Health and Place. 2012. Volume 18, Issue 1, 31-38. ISSN: 1353-8292.

[6] J. Wang, \& W. F. Straub, "An Investigation into the coaching approach of a successful world class soccer coach: anson dorrance," International Journal of Sports Science \& Coaching. 2012. Volume 7 Number 3, 431-446.

[7] S. Aida, T. A. Muhamad, S. Surat, \& M. F. Ahmad, "coaching style and mental toughness among uitm's football players," Journal of Sports Science and Physical Education, Malaysia. 2016. Vol 5 Issue 1, 22-34. ISSN: 2232-1926.

[8] J. W. Creswell, Research design pendekatan kualitatif, kuantitatif, dan mixed. Yogyakarta: Pustaka Pelajar. 2010. 